\title{
Treatment of fractures and other orthopedic problems in cats and dogs using versatile external fixator
}

\author{
Tratamento de fraturas de extremidades de cães e gatos usando fixador \\ externo versátil
}

\author{
Yetkin Öztürk ${ }^{1}$ (D); Serhat Özsoy² (D) \\ ${ }^{1}$ İstanbul Technical University, Science and Literature Faculty, Molecular Biology and Genetics Department, İstanbul, Turkey \\ ${ }^{2}$ Istanbul University-Cerrahpasa, Veterinary Faculty, Surgery Department, İstanbul, Turkey
}

\begin{abstract}
Many complicated bone fractures can be healed by different techniques including linear external fixation. New generation linear external fixators enhanced the scope of application for bone fractures by mechanical progress. Difficulties include implementing enough pins through fixation clamps to the comminuted fragments or clamp addition and fixing it properly to the rod with the correct pin insertion angle. Effective configurations may not always result. This study sought to reveal the clinical efficiency of modified clamps of a versatile external fixator (VEF) to fix different types of fractures and orthopedic problems according to the radiographic and clinical results. We used this fixator on 17 cats and 17 dogs of different ages and sizes, having different types of antebrachium, humerus, tibia, ulna fractures, and bone-muscle deformities. Clamps had different features to connect fixator pins. Many fixator configurations were created according to the fracture type and body weight of the animals. The most used ones were unilateral and bilateral configurations. The callus formation and visual gait analysis were observed after the operations, until the removal of the fixator. After fixator removal, the visual gait status of the limbs was excellent in $67 \%$ of the cases, good in $15 \%$, fair in $12 \%$, and poor in $6 \%$. We found that rods and fixator pins were connected easily by semi-locked clamps. Also, the double pin holding clamps saved space on the fixation rod by the application of two pins through one clamp. We think that clamps of versatile external fixators can easily be constructed to limb fractures and save time during surgery.
\end{abstract}

Keywords: Clamps. Bone fractures. Linear fixators. Osteosynthesis. Fixator pins.

\section{RESUMO}

Diversas fraturas ósseas complicadas podem ser tratadas por diferentes técnicas, incluindo fixadores externos lineares. Os fixadores externos lineares de nova geração aumentaram o escopo de aplicação para fraturas ósseas devido ao progresso mecânico. A dificuldade é implementar um número suficiente de pinos através de clamps de fixação aos fragmentos osseos ou adição de clamps com fixação adequadamente à haste com o ângulo correto de inserção do pino. As configurações eficazes nem sempre podem ser realizadas. Este estudo pretendia revelar a eficácia clínica das clamps modificadas de um fixador externo versátil para corrigir diferentes tipos de fraturas e problemas ortopédicos de acordo com os resultados radiográficos e clínicos. O fixador foi utilizado em 17 gatos e 17 cães de diferentes idades e tamanhos, com diferentes tipos de antebraço, úmero, tíbia, fratura de ulna e deformidades ósseo-musculares. Os clamps tinham recursos diferentes para conectar os pinos do fixador. Muitas configurações de fixadores foram criadas de acordo com o tipo de fratura e peso corporal dos animais. As mais utilizadas foram as configurações unilateral e bilateral. A formação do calo e a análise visual da marcha foram observadas após as cirurgias, até a retirada do fixador. Após a retirada do fixador, a utilização dos membros foi excelente em $67 \%$ dos casos, bom em $15 \%$ dos casos, regular em $12 \%$ dos casos, ruim em $6 \%$ dos casos. Concluímos que as hastes e os pinos do fixador foram facilmente conectados por clamps semitravados. Além disso, os clamps de fixação de pino duplo economizaram espaço na haste de fixação com a aplicação de dois pinos em clamp. Acreditamos que os clamps de fixadores externos versáteis podem ser facilmente construídas para fraturas de membros, economizando tempo na cirurgia.

Palavras-chave: Clamp. Fraturas ósseas. Fixadores lineares. Osteossíntese. Pinos fixadores. 
Correspondence to:

Yetkin Öztürk

İstanbul Technical University, Science and Literature Faculty,

Molecular Biology and Genetics Department

İstanbul Technical University, Ayazaga Campus, Science

and Literature Faculty, Molecular Biology and Genetics

Department, Maslak

34469, İstanbul, Turkey

e-mail: yetkinozturk@itu.edu.tr

Received: March 06, 2021

Approved: August 17, 2021

How to cite: Öztürk Y, Özsoy S. Treatment of fractures and other orthopedic problems in cats and dogs using versatile external fixator. Braz J Vet Res Anim Sci. 2021;58:e182908. https://doi.org/10.11606/issn.1678-4456.bjvras.2021.182908

\section{Introduction}

Bone plates and interlocking nails can be used with limb fractures. However, external fixators have also been used widely for stabilization (Shahar, 2000; Wander, 2019). They have mainly been applied to open, infected, comminuted fractures, arthrodesis, and corrective osteotomies in human and veterinary orthopedics (Petfield et al., 2017; White et al., 2003).

Some critical biomechanical factors are positive profile pins (Fragomen \& Rozbruch, 2007), and the number and thickness of the pins (Canapp, 2004). These factors affect the fixator's stabilization (Giotakis \& Narayan, 2007; Roe, 2014). Although circular external fixators are the most rigid fixators and thin Steinmann pins are applicable, linear fixators are less expensive (Piermattei et al., 2016).

IMEX-SK and Securos external fixation systems include new generation linear external fixators (Kraus et al., 2003). The mechanics of these clamps and their stiffness make them more advantageous than Kirschner-Ehmer splints. These fixators have ease of use during fixator construction at the operations (Lewis et al., 2001). However, problems can still occur, and transarticular frames are significantly more likely to develop mechanical complications (Beever et al., 2018).

Although external fixation is a successful method, it may not always be easy to apply them on comminuted and short distal fractures (Witte et al., 2014). All the Steinmann fixator pins have to be inserted using a proper technique, considering the tissue damage and the safe corridors for fixator pin application (Seibert et al., 2011; Palmer, 2012). It may not always be possible to use safe corridors to insert the pins without damaging vessels and muscle tissue according to the fracture type, fracture localization, and soft tissue injuries (Piermattei et al., 2016). A concession of the ideal ways is made in many cases (Kraus et al., 2003). There may not be enough room to insert a pin through the short oblique fragments (Guerin et al., 1998). The rods are not pliable, and passing the pins through the bone cortex is not easy in comminuted and distal fractures (Beck \& Simpson, 1999). This can lead to fixation application difficulties and complications (Clarke \& Carmichael, 2006). A higher complication rate has been found in the femur, tarsus, and radius/ulna than the other long bone fractures. This affects the healing time and fixation strength (Beever et al., 2017). New clamps may contribute to better fixator constructs (Wander, 2019).

In this study, we aimed to determine the ease of application of VEF, possible lesser clamp usage, evaluate clinical and radiological results. We made clamp modifications and produced a versatile (linear) external fixator (VEF) that allows the usage of $1.2 \mathrm{~mm}$ Kirschner pins in small dogs and cats. Also, semi-locked and standard clamps were questioned to investigate if easier fixator construction can be made during fracture fixation. Although similar clamps have been used in human medicine, it is not likely to be used in veterinary medicine.

\section{Material and Methods}

\section{VEF fixator}

VEF (Serbay ${ }^{\circ}$ ) has $4 \mathrm{~mm}$ and $6 \mathrm{~mm}$ diameter titanium alloy connection rods. These are 8, 10,11, 12, $20 \mathrm{~cm}$ long. Fixator has three different types of clamps. The first type is the standard clamp, which is attached from the end of the rods. This clamp is different from the IMEX-SK and Securos clamps. It is made of two parts. These are connected by teeth, which are actually like a gearwheel. Each part has a hole. Both parts are equal to each other, and a blue pin holder is inserted into one of them. The rod passes from the other part. Both the two parts and the teeth between them are compressed when tightened with a screwdriver. The second type of clamp can be attached directly over the rod. It is called a semi-locked clamp. It is made of two different parts with teeth between them. One part holds the fixator pin, and the other is locked to the rod. The third type of clamp is a double pin holding clamp which can hold two Steinmann pins. These clamps can hold $1.2 \mathrm{~mm}$ and bigger diameter Steinmann pins. This clamp also has two different parts. One part holds two Steinman pins while the other holds the rod. It also has teeth between two parts for stabilizing each other.

The blue pin holder is inserted into the hole of the clamp. A fixator pin can be applied through this pin holder after it is placed into the clamp (except double-pin holding clamp). 
We used $3 \mathrm{~mm}$ and $4 \mathrm{~mm}$ titanium alloy positive profile pins and $1.2 \mathrm{~mm}$ and $1.5 \mathrm{~mm}$ smooth Steinmann pins. VEF components are shown in Figure 1.

\section{Surgical procedures:}

The patients were brought to İstanbul UniversityCerrahpaşa, Faculty of Veterinary Medicine, Department of Surgery, with the humerus, radius/ulna, femur, tibia, talus fractures, malunion, and bone deformities. The Local Ethics Committee of Animal Experiments approved the study at İstanbul University-Cerrahpaşa with report number 72 and supported by İstanbul University-Cerrahpaşa Scientific Research Projects (BAP) Unit. It is composed of a Ph.D. thesis. Informed consents from the owners of the patients were also obtained. Radiologic evaluations were made with OREX PcCR 1417 x-ray machine. $1 \mathrm{mg} / \mathrm{kg}$ Xylazine hydrochloride intravenously (IV) as preanesthetic and $5 \mathrm{mg} / \mathrm{kg}$ Ketamine hydrochloride (IV) for general anesthetic were used. Animals were intubated just after ketamine hydrochloride administration. Anesthesia was sustained by isoflurane or sevoflurane by inhalation gas anesthesia machine with no signs of pain. Ceftriaxone sodium $22 \mathrm{mg} / \mathrm{kg}$ IV was administered as a preoperative antibiotic. The choice of fixator configuration was decided by the authors (surgeons). Body weight, age, gender, breed, and information about the orthopedic problem were recorded. We (surgeons) evaluated gait analysis at controls according to the classification in Table 1 as Fox et al. (1995) previously described. Some clients could not bring their pets. We evaluated those dogs and cats by asking about the gait status of clients' pets. It is classified as excellent, good, fair, and poor according to visual gait analysis. Bone union was interpreted according to the radiological findings regarding complete callus formation or not. Clients were asked to come for postoperative radiographic controls every 15 days. Some of them communicated by phone. Union time and complications were recorded.

\section{Statistical analysis}

Collected data were statistically analyzed with Microsoft excel. The student's t-test was used to evaluate the null hypothesis between the type of fracture and healing time. The fracture type is considered both open or closed and simple or complex. The presence of minor or major complications and healing time together with clamp type (standard or double pin holding or semi-locked clamp) and healing time were also evaluated.

The chi-square test (IBM SPSS Statistics 27) was also used to assess the null hypothesis between the type of fracture (open or closed fracture and simple or complex fracture) and walking grade. Clamp type (standard or double pin holding or semi-locked clamp) and bone union, clamp type, and walking grade were evaluated. The level of significance was set at $\mathrm{P}<.05$ for all the tests.

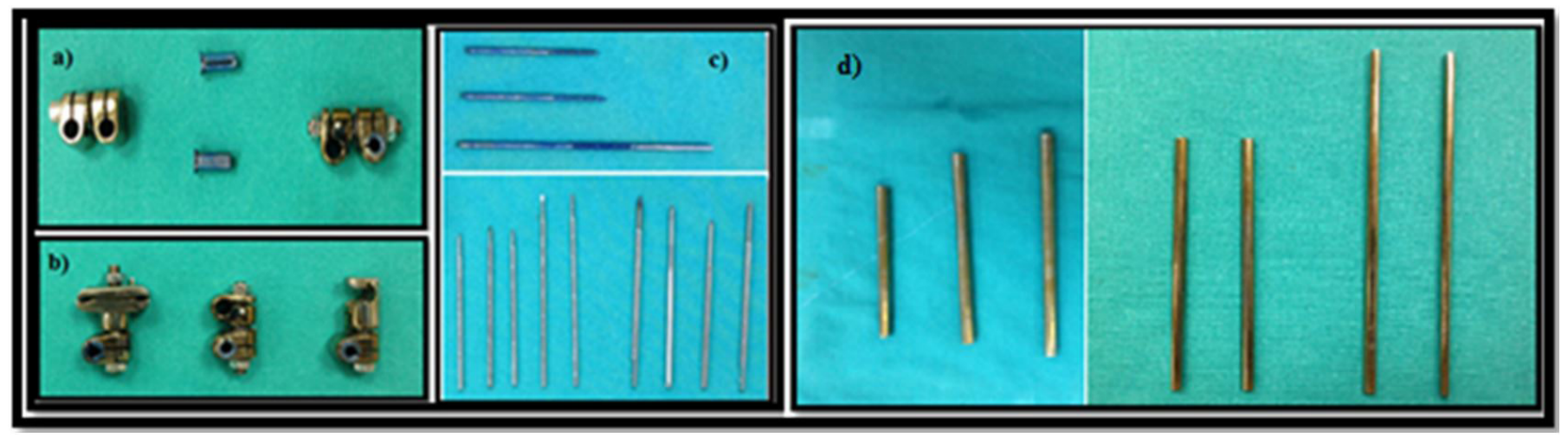

Figure 1 - Clamps and fixator pins of the VEF. (a) shows standard clamps and blue pin holders; (b) shows on the left two Steinmann pin holding clamps, in the middle standard clamp, on the right semi-locked clamp. Figure 1c shows $3 \mathrm{~mm}$ and $4 \mathrm{~mm}$ diameter positive profile pins used in dog and cat cases; (d) shows titanium connection rods.

Table 1 - Clinical evaluation of the visual gait status of dog and cat cases

\begin{tabular}{ccl}
\hline Grade & Visual gait status & \multicolumn{1}{c}{ Definition } \\
\hline I & Excellent & $\begin{array}{l}\text { Complete usage of the limb when standing, walking, running and able to give the full body } \\
\text { weight to the leg }\end{array}$ \\
II & Good & Slight lameness after running \\
III & Fair & Continuous lameness but being able to give body weight to the leg \\
IV & Poor & Severe lameness and not able to give body weight to the leg \\
\hline
\end{tabular}




\section{Results}

Thirty-five orthopedic problems of 17 dogs and 17 cats were operated on and evaluated. Six cats were female and 11 were male, while five dogs were female and 12 were male. Eight dog breeds and three cat breeds were operated in the study. The mean age was 3.78 years in dogs (median, two years; range between 0.5 years to 13 ). Mean age was 1.98 years in cats (median, one year; range between 0.5 years to 6). Mean body weight was $20.47 \mathrm{~kg}$ for dogs (median, 23; range, 7 to $32 \mathrm{~kg}$ ) and $3.25 \mathrm{~kg}$ for cats (median, $3.2 \mathrm{~kg}$; range, 2.5 to $5.2 \mathrm{~kg}$ ). Eleven (32.3\%) of the patients were brought in due to unknown trauma, 7 (20.6\%) traffic accident, 6 (17.7\%) fall from height, 3 (8.8\%) squeezed to car engine, 2 (5.9\%) human-caused trauma, 2 (5.9\%) gunshot and 3 (8.8\%) developmental problems.

Thirty (85\%) fractures (1 dog had bilateral antebrachium fracture), 1 (3\%) short femur (osteotomy was performed), 1 (3\%) elbow dysplasia (fixator pins were applied to humerus and radius, and then fixed with the VEF), 1 (3\%) angular deformity (osteotomy was performed), 1 (3\%) malunion (osteotomy was performed), 1 (3\%) contracture (fixator pins were applied to femur and tibia, and then fixed with the VEF) in 34 patients ( 17 cats and 17 dogs) were operated. Five (14\%) of the operations were performed on the femur, $18(51 \%)$ on the tibia, 8 (23\%) on antebrachium, $2(6 \%)$ on the humerus, $1(3 \%)$ on talus, and $1(3 \%)$ on humerus and antebrahium for elbow dysplasia. Ten $(33 \%)$ of the fractures were open and $20(67 \%)$ were closed.

Type Ia ( 7 cases, $20 \%$ ), type Ib (10 cases, $28 \%$ ), type Ib with tie-in ( 1 case, $3 \%$ ), type II ( 7 cases, $20 \%$ ), unilateral tie-in ( 8 cases, $23 \%)$, bilateral tie-in (1 case, $3 \%)$ and type III (1 case, $3 \%$ ) fixator configurations were composed for fixation. A total of 35 operations were performed. Out of the 35 operations, standard clamps were used in
$23(65 \%)$ of them, in 3 (9\%) double pin holding, and in $9(26 \%)$ semi-locked clamps were used. Destabilization was performed in 15 (42\%) patients when callus formation was started. One cat died on the postoperative fifth day. All the patients had minor pin tract infections. Two (5.9\%) cases of 34 operations ( 33 alive patients) had a severe infection. Pin breakage occurred in 7 (20.6\%) cases, and fixator failure was observed in $2(5.9 \%)$ cases. Fixator failures were due to pin loosening at the bone, and they were reoperated. There was no loosening between pin-clamp or bar-clamp connections of the VEF. All the semi-locked clamps were implemented to bars in seconds. Other clamps were attached from the end of the bars.

According to postoperative rechecks, out of 33 patients, four patients had mineralized callus formation on day 30 (12.1\%), seven on day 45 (21.2\%), seven on day 60 (21.2\%), five on day 75 (15.2\%), five on day $90(15.2 \%)$, one on day 120 day (3\%). Two (6\%) patients had no callus formation. Callus formation time was not properly known in two (6\%) patients due to the poor connection for rechecks. The average number of these rechecks was 2.6 (range 1 to 6 ). The mean mineralized callus formation for 31 animals ( 2 unknown) was 58 days.

The walking grades of the patients according to the visual gait analysis were excellent in $22(66.7 \%)$ cases, good in $5(15.2 \%)$, fair in $4(12.1 \%)$, and poor in $2(6 \%)$. Orthopedic evaluations and the healing status of the animals were shown in Table 2.

No significant differences between open or closed fractures $(\mathrm{P}=0.54)$, simple or complex fractures $(\mathrm{P}=0.64)$, standard or double pin holding, or semi-locked clamps $(\mathrm{P}=0.28)$ were determined.

Preoperative and postoperative radiographs of VEF implementations of three cases were shown in Figures 2, 3, and 4.
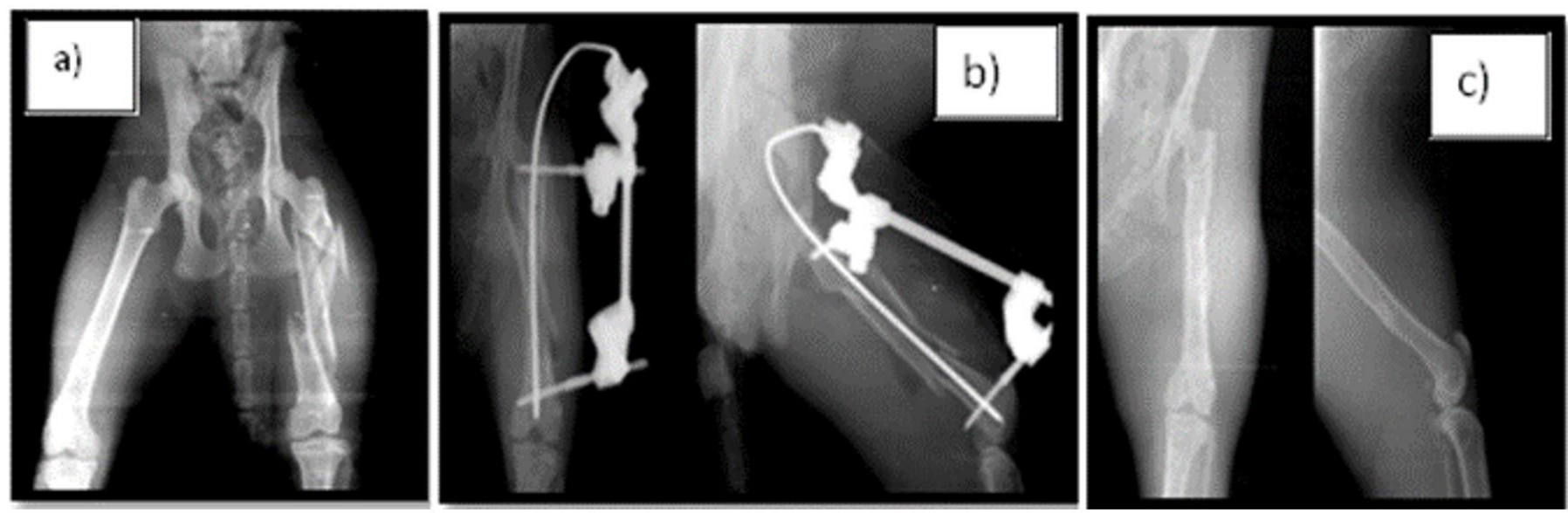

Figure 2 - Figure 3a shows a preoperative radiograph of comminuted fracture of the cat's femur, $3 \mathrm{~b}$ postoperative radiograph, and $3 \mathrm{c}$ after fixator removal (case 4). 
Table 2 - Fracture types, fixation methods, clamp types, and healing status of the cases

\begin{tabular}{|c|c|c|c|c|c|c|c|}
\hline $\begin{array}{l}\text { Case } \\
\text { No }\end{array}$ & Age, species & Weight, gender & $\begin{array}{l}\text { Fracture type or the } \\
\text { orthopedic problem }\end{array}$ & $\begin{array}{l}\text { External } \\
\text { Fixation } \\
\text { Method }\end{array}$ & Clamp Type & $\begin{array}{l}\text { Union } \\
\text { Time }\end{array}$ & $\begin{array}{l}\text { Visual Gait Analysis } \\
\text { (According to } \\
\text { Table 1) }\end{array}$ \\
\hline 1 & 6 months cat & $\begin{array}{l}2.5 \mathrm{~kg} \\
\text { male }\end{array}$ & Femur contracture & Type la & $\begin{array}{l}\text { Standard } \\
\text { clamp }\end{array}$ & 45. day & III \\
\hline 2 & 7 months cat & $\begin{array}{l}2.7 \mathrm{~kg} \\
\text { female }\end{array}$ & $\begin{array}{l}\text { Sagital diaphyseal } \\
\text { humerus fracture }\end{array}$ & Type la & $\begin{array}{l}\text { Standard } \\
\text { clamp }\end{array}$ & 45. day & I \\
\hline 3 & $\begin{array}{l}5 \text { years } \\
\text { cat }\end{array}$ & $\begin{array}{l}3.7 \mathrm{~kg} \\
\text { male }\end{array}$ & $\begin{array}{l}\text { Comminuted tibia } \\
\text { fracture }\end{array}$ & Type Ib & $\begin{array}{l}\text { Standard } \\
\text { clamp }\end{array}$ & 60. day & I \\
\hline 4 & $\begin{array}{l}2 \text { years } \\
\text { cat }\end{array}$ & $\begin{array}{l}3.2 \mathrm{~kg} \\
\text { female }\end{array}$ & $\begin{array}{l}\text { Comminuted femur } \\
\text { fracture }\end{array}$ & $\begin{array}{l}\text { Unilateral with } \\
\text { tie-in }\end{array}$ & $\begin{array}{l}\text { Standard } \\
\text { clamp }\end{array}$ & 75. day & I \\
\hline 5 & 7 months cat & $\begin{array}{l}2.5 \mathrm{~kg} \\
\text { male }\end{array}$ & Antebrachium fracture & Type II & $\begin{array}{l}\text { Standard } \\
\text { clamp }\end{array}$ & 60. day & ॥ \\
\hline 6 & $\begin{array}{l}6 \text { years } \\
\text { cat }\end{array}$ & $\begin{array}{l}5.2 \mathrm{~kg} \\
\text { female }\end{array}$ & Tibia fracture & $\begin{array}{l}\text { Type II with a } \\
\text { tie-in }\end{array}$ & $\begin{array}{l}\text { Standard } \\
\text { clamp }\end{array}$ & 60. day & I \\
\hline 7 & $\begin{array}{l}1,5 \text { year } \\
\text { cat }\end{array}$ & $\begin{array}{l}3.2 \mathrm{~kg} \\
\text { male }\end{array}$ & Tibia fracture & Type II & $\begin{array}{l}\text { Standard } \\
\text { clamp }\end{array}$ & 90. day & I \\
\hline 8 & $\begin{array}{l}1 \text { year } \\
\text { cat }\end{array}$ & $\begin{array}{l}3.0 \mathrm{~kg} \\
\text { male }\end{array}$ & $\begin{array}{l}\text { Open tibia } \\
\text { fracture }\end{array}$ & Type II & $\begin{array}{l}\text { Standard } \\
\text { clamp }\end{array}$ & 60. day & I \\
\hline 9 & 6 months cat & $\begin{array}{l}2.8 \mathrm{~kg} \\
\text { male }\end{array}$ & $\begin{array}{l}\text { Open tibia } \\
\text { fracture }\end{array}$ & $\begin{array}{l}\text { Unilateral with } \\
\text { tie-in }\end{array}$ & $\begin{array}{l}\text { Standard } \\
\text { clamp }\end{array}$ & 45. day & I \\
\hline 10 & $\begin{array}{l}5 \text { years } \\
\text { cat }\end{array}$ & $\begin{array}{l}3.9 \mathrm{~kg} \\
\text { male }\end{array}$ & $\begin{array}{l}\text { Open oblique distal } \\
\text { tibia fracture }\end{array}$ & Type Ib & $\begin{array}{l}\text { Standard } \\
\text { clamp }\end{array}$ & 90. day & I \\
\hline 11 & 10 months cat & $\begin{array}{l}3.4 \mathrm{~kg} \\
\text { female }\end{array}$ & $\begin{array}{l}\text { Open tibia } \\
\text { fracture }\end{array}$ & $\begin{array}{l}\text { Unilateral with } \\
\text { tie-in }\end{array}$ & $\begin{array}{l}\text { Standard } \\
\text { clamp }\end{array}$ & 75. day & I \\
\hline 12 & $\begin{array}{l}1 \text { year } \\
\text { cat }\end{array}$ & $\begin{array}{l}3.2 \mathrm{~kg} \\
\text { male }\end{array}$ & $\begin{array}{l}\text { Diaphyseal sagittal } \\
\text { antebrachium fracture }\end{array}$ & Type la & $\begin{array}{l}\text { Standard } \\
\text { clamp }\end{array}$ & 45. day & I \\
\hline 13 & $\begin{array}{l}1 \text { year } \\
\text { cat }\end{array}$ & $\begin{array}{l}3.3 \mathrm{~kg} \\
\text { male }\end{array}$ & $\begin{array}{l}\text { Comminuted } \\
\text { antebrachium fracture }\end{array}$ & Type II & $\begin{array}{l}\text { Standard } \\
\text { clamp }\end{array}$ & 45. day & I \\
\hline 14 & 6 months cat & $\begin{array}{l}2.6 \mathrm{~kg} \\
\text { male }\end{array}$ & $\begin{array}{l}\text { Open tibia } \\
\text { fracture }\end{array}$ & Type la & $\begin{array}{l}\text { Standard } \\
\text { clamp }\end{array}$ & - & $\begin{array}{l}\text { Died on postoperative } \\
5 . \text { day }\end{array}$ \\
\hline 15 & $\begin{array}{l}3 \text { years } \\
\text { cat }\end{array}$ & $\begin{array}{l}3.7 \mathrm{~kg} \\
\text { male }\end{array}$ & Tibia fracture & Type la & $\begin{array}{l}\text { Standard } \\
\text { clamp }\end{array}$ & 75. day & I \\
\hline 16 & 9 months cat & $\begin{array}{l}2.8 \mathrm{~kg} \\
\text { female }\end{array}$ & $\begin{array}{l}\text { Comminuted femur } \\
\text { fracture }\end{array}$ & $\begin{array}{l}\text { Unilateral with } \\
\text { tie-in }\end{array}$ & $\begin{array}{l}\text { Standard } \\
\text { clamp }\end{array}$ & Unknown & I \\
\hline 17 & $\begin{array}{l}4 \text { years } \\
\text { cat }\end{array}$ & $\begin{array}{l}3.6 \mathrm{~kg} \\
\text { female }\end{array}$ & $\begin{array}{l}\text { Diaphyseal sagittal } \\
\text { tibia fracture }\end{array}$ & Type la & $\begin{array}{l}\text { Standard } \\
\text { clamp }\end{array}$ & 45. day & I \\
\hline 18 & $\begin{array}{l}5 \text { years } \\
\text { dog }\end{array}$ & $\begin{array}{c}28 \mathrm{~kg} \\
\text { female }\end{array}$ & $\begin{array}{l}\text { Diaphyseal sagittal } \\
\text { antebrachium fracture } \\
\text { (bilateral) }\end{array}$ & $\begin{array}{l}\text { Type Ib } \\
\text { both legs }\end{array}$ & $\begin{array}{l}\text { Semi-locked } \\
\text { clamp }\end{array}$ & 60. day & ॥ \\
\hline 19 & $\begin{array}{c}2 \text { years } \\
\text { dog }\end{array}$ & $\begin{array}{l}32 \mathrm{~kg} \\
\text { male }\end{array}$ & $\begin{array}{l}\text { Oblique tibia } \\
\text { fracture }\end{array}$ & Type Ib & $\begin{array}{l}\text { Standard } \\
\text { clamp }\end{array}$ & 60. day & I \\
\hline 20 & $\begin{array}{l}9 \text { years } \\
\text { dog }\end{array}$ & $\begin{array}{l}7 \mathrm{~kg} \\
\text { male }\end{array}$ & Tibia fracture & Type Ib & $\begin{array}{l}\text { Standard } \\
\text { clamp }\end{array}$ & 90. day & I \\
\hline 21 & $\begin{array}{l}7 \text { years } \\
\text { dog }\end{array}$ & $\begin{array}{l}21 \mathrm{~kg} \\
\text { male }\end{array}$ & $\begin{array}{l}\text { Open comminuted } \\
\text { proximal antebrachium } \\
\text { fracture }\end{array}$ & Type III & $\begin{array}{l}\text { Double pin } \\
\text { holding clamp }\end{array}$ & $\begin{array}{c}\text { No } \\
\text { callus } \\
\text { formation }\end{array}$ & III \\
\hline 22 & 5 months dog & $\begin{array}{c}18 \mathrm{~kg} \\
\text { female }\end{array}$ & $\begin{array}{l}\text { Open proximal tibia } \\
\text { fracture }\end{array}$ & Type II & $\begin{array}{l}\text { Standard } \\
\text { clamp }\end{array}$ & 30. day & I \\
\hline 23 & 7 months dog & $\begin{array}{c}8 \mathrm{~kg} \\
\text { female }\end{array}$ & Short femur & $\begin{array}{l}\text { Type la after } \\
\text { osteotomy }\end{array}$ & $\begin{array}{l}\text { Semi-locked } \\
\text { clamp }\end{array}$ & 30. day & IV \\
\hline 24 & $\begin{array}{c}2 \text { years } \\
\text { dog }\end{array}$ & $\begin{array}{l}25 \mathrm{~kg} \\
\text { male }\end{array}$ & Femur fracture & $\begin{array}{l}\text { Unilateral with } \\
\text { tie-in }\end{array}$ & $\begin{array}{l}\text { Standard } \\
\text { clamp }\end{array}$ & 75. day & ॥ \\
\hline 25 & $\begin{array}{l}10 \text { months } \\
\text { dog }\end{array}$ & $\begin{array}{l}23 \mathrm{~kg} \\
\text { male }\end{array}$ & Elbow dysplasia & $\begin{array}{l}\text { Unilateral with } \\
\text { tie-in }\end{array}$ & $\begin{array}{l}\text { Semi-locked } \\
\text { clamp }\end{array}$ & $\begin{array}{c}\text { No } \\
\text { callus } \\
\text { formation }\end{array}$ & IV \\
\hline 26 & $\begin{array}{l}3 \text { years } \\
\text { dog }\end{array}$ & $\begin{array}{l}28 \mathrm{~kg} \\
\text { male }\end{array}$ & Antebrachium fracture & Type Ib & $\begin{array}{l}\text { Semi-locked } \\
\text { clamp }\end{array}$ & 75. day & I \\
\hline 27 & $\begin{array}{l}3,5 \text { months } \\
\text { dog }\end{array}$ & $\begin{array}{l}9 \mathrm{~kg} \\
\text { male }\end{array}$ & Oblique tibia fracture & Type II & $\begin{array}{l}\text { Standard } \\
\text { clamp }\end{array}$ & 30. day & I \\
\hline 28 & $\begin{array}{l}13 \text { years } \\
\text { dog }\end{array}$ & $\begin{array}{l}24 \mathrm{~kg} \\
\text { male }\end{array}$ & $\begin{array}{l}\text { Sagital diaphyseal tibia } \\
\text { fracture }\end{array}$ & Type Ib & $\begin{array}{l}\text { Semi-locked } \\
\text { clamp }\end{array}$ & 45. day & I \\
\hline
\end{tabular}


Table 2 - Continued...

\begin{tabular}{|c|c|c|c|c|c|c|c|}
\hline $\begin{array}{l}\text { Case } \\
\text { No }\end{array}$ & Age, species & Weight, gender & $\begin{array}{l}\text { Fracture type or the } \\
\text { orthopedic problem }\end{array}$ & $\begin{array}{l}\text { External } \\
\text { Fixation } \\
\text { Method }\end{array}$ & Clamp Type & $\begin{array}{l}\text { Union } \\
\text { Time }\end{array}$ & $\begin{array}{l}\text { Visual Gait Analysis } \\
\text { (According to } \\
\text { Table 1) }\end{array}$ \\
\hline 29 & $\begin{array}{l}11 \text { years } \\
\text { dog }\end{array}$ & $\begin{array}{l}28 \mathrm{~kg} \\
\text { male }\end{array}$ & $\begin{array}{l}\text { Open talus } \\
\text { fracture }\end{array}$ & Type Ib & $\begin{array}{l}\text { Standard } \\
\text { clamp }\end{array}$ & Unknown & III \\
\hline 30 & $\begin{array}{c}6 \text { years } \\
\text { dog }\end{array}$ & $\begin{array}{l}26 \mathrm{~kg} \\
\text { male }\end{array}$ & $\begin{array}{l}\text { Open tibia } \\
\text { fracture }\end{array}$ & Type Ib & $\begin{array}{l}\text { Semi-locked } \\
\text { clamp }\end{array}$ & 90. day & I \\
\hline 31 & 6 months dog & $\begin{array}{c}23 \mathrm{~kg} \\
\text { female }\end{array}$ & $\begin{array}{l}\text { Angular deformity on } \\
\text { antebrachium }\end{array}$ & Type Ib & $\begin{array}{l}\text { Semi-locked } \\
\text { clamp }\end{array}$ & 60. day & III \\
\hline 32 & 5 months dog & $\begin{array}{c}15 \mathrm{~kg} \\
\text { female }\end{array}$ & $\begin{array}{l}\text { Malunion of } \\
\text { tibia }\end{array}$ & $\begin{array}{l}\text { Type II after } \\
\text { corrective } \\
\text { osteotomy }\end{array}$ & $\begin{array}{l}\text { Double pin } \\
\text { holding clamp }\end{array}$ & 30. day & I \\
\hline 33 & $\begin{array}{c}2 \text { years } \\
\text { dog }\end{array}$ & $\begin{array}{l}19 \mathrm{~kg} \\
\text { male }\end{array}$ & $\begin{array}{l}\text { Open tibia } \\
\text { fracture }\end{array}$ & $\begin{array}{l}\text { Unilateral with } \\
\text { tie-in }\end{array}$ & $\begin{array}{l}\text { Double pin } \\
\text { holding clamp }\end{array}$ & 90. day & II \\
\hline 34 & $\begin{array}{l}1 \text { year } \\
\text { dog }\end{array}$ & $\begin{array}{l}14 \mathrm{~kg} \\
\text { male }\end{array}$ & $\begin{array}{l}\text { Comminuted humerus } \\
\text { fracture }\end{array}$ & $\begin{array}{l}\text { Unilateral with } \\
\text { tie-in }\end{array}$ & $\begin{array}{l}\text { Semi-locked } \\
\text { clamp }\end{array}$ & 120. day & II \\
\hline
\end{tabular}
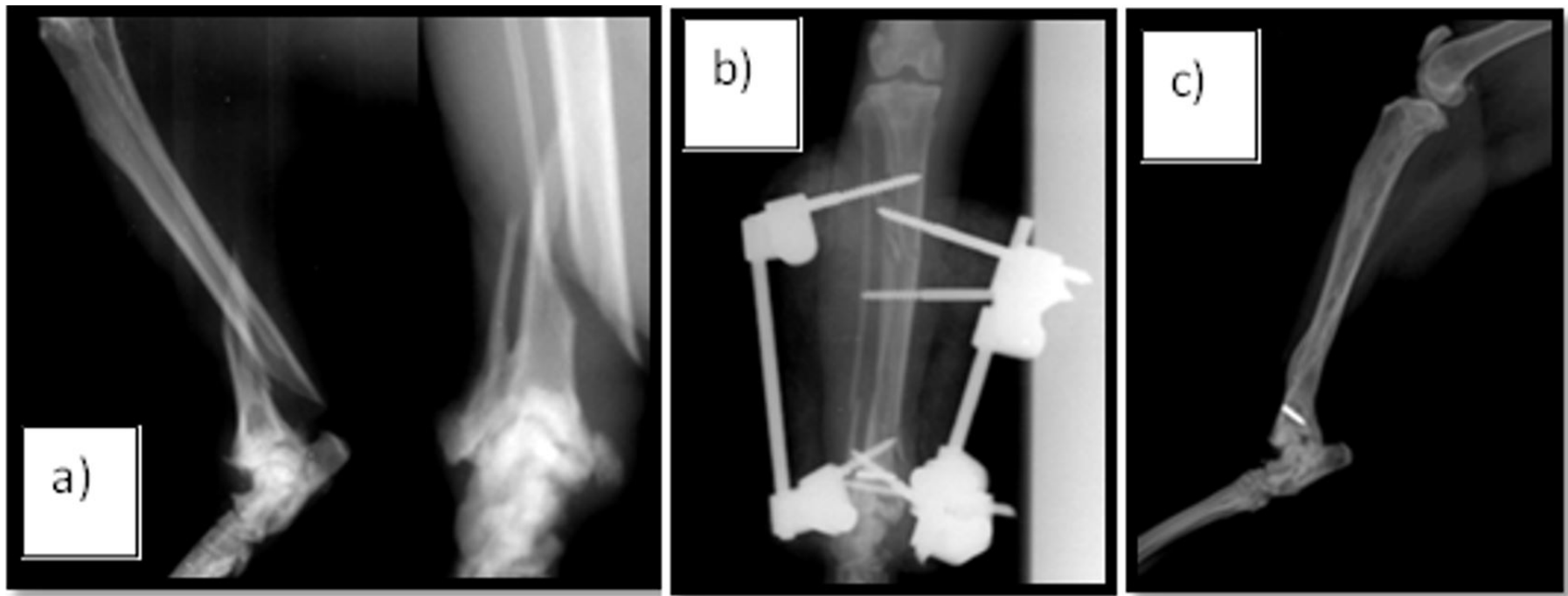

Figure 3 - Figure 2a shows distal oblique fracture of the tibia in a cat before operation and Figure $2 \mathrm{~b}$ just after pin implementation (case 10). Figure $2 \mathrm{c}$ is the radiograph after fixator removal. One fixator pin was broken and stayed inside the bone.
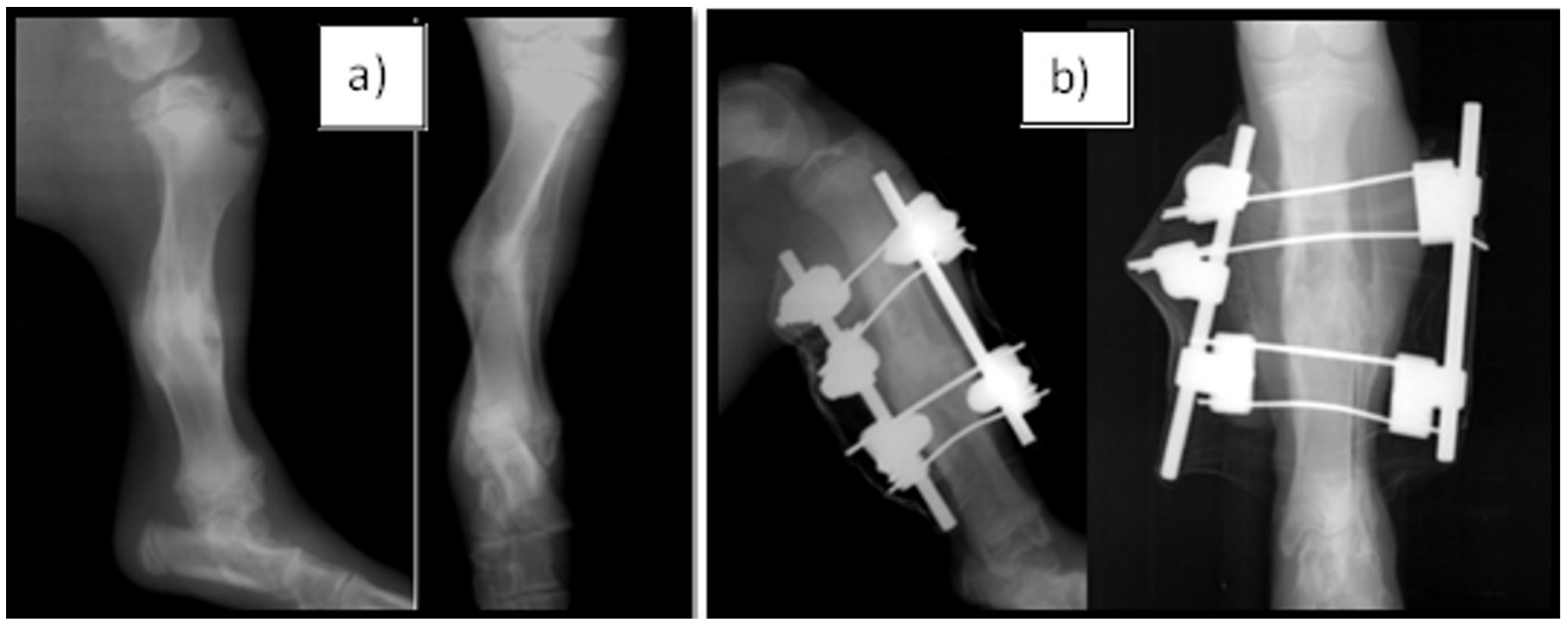

Figure $4-5$ months old dog with malunion of the tibia (case 32). Figure $4 \mathrm{a}$ is the preoperative radiograph and Figure $4 \mathrm{~b}$ is the postoperative radiograph on day 30 . 


\section{Discussion}

External fixators have basic implementation techniques. The parts of the external fixator should be arranged according to the patient's size, age, the character of the animal, and fracture type (Marcellin-Little, 2003). In our study, we used different configurations according to the fracture type, age, and body weight of the animal.

Various fixator apparatus can be designed using KirschnerEhmer, IMEX-SK, and Securos fixator models. Clamps of these fixators have different features for fixator stabilization (Piermattei et al., 2016). The clamps of the Securos and IMEXSK fixators are attached from the rods' edge (Kraus et al., 2003; Sylvestre, 2019). Standard and double-pin holding clamps of VEF are also attached from the rods' edge, but semi-locked clamps can be attached anywhere on the rod. Kirschner-Ehmer clamp, Securos clamp, IMEX-SK clamp (Corr, 2005), and VEF's semi-locked clamps are shown in Figure 5. Complex fixator structures can be made quickly and easily with semi-locked clamps due to their ease of pluggability. Quick connection with these clamps has saved time in applying type III and type Ib fixations especially. All the clamps of VEF could rotate $360^{\circ}$. This provides ease of usability as other fixators do. Semi-locked clamps were the best to gain time when compared to the standard and double pin holding clamps.

Fixation of the rods together using another rod improves the construct's strength in type Ib and type III applications
(Johnson, 2018). The callus hardness increases during the bone union. This allows conveying the body weight through the fracture side. Increasing the load on the fractured bone by disassembling the fixator allows limited axial movement between fragments and accelerates the final stages of bone healing (Foxworthy \& Pringle, 1995). For this reason, adjustability of the robustness of the fixator is very important for bone union (Mora \& Forriol, 2000; Auger et al., 2002; Canapp, 2004; Rovesti, 2016). Fifteen cases healed by increasing the load on the fractured side. Quick destabilization of the semi-locked clamps enabled the use of low-dose anesthesia. It was achieved by disassembling the semi-locked clamps of VEF that connected the fixation rods or removing the intramedullary pin used in tie-in fixations. VEF's semi-locked clamps provided a significant convenience to reapply a new fixation pin when a correction was needed after postoperative radiography.

At least two fixator pins have to be implemented to each fragment, but three or more are frequently needed (Aronsohn \& Burk, 2009). For not to crack the bone, the pin's diameter should be a maximum of $20-25 \%$ of the bone diameter (Johnson, 2018). A diameter of a minimum of $1.6 \mathrm{~mm}$ pin in the Securos fixator and $0.9 \mathrm{~mm}$ pin in the IMEX-SK fixator can be used for fixation, as Corr (2005) reported. It is advantageous to be able to use suitable diameter fixator pins in young or small animals. It is possible to use both $1.2 \mathrm{~mm}$ (or larger) diameter smooth Steinmann and
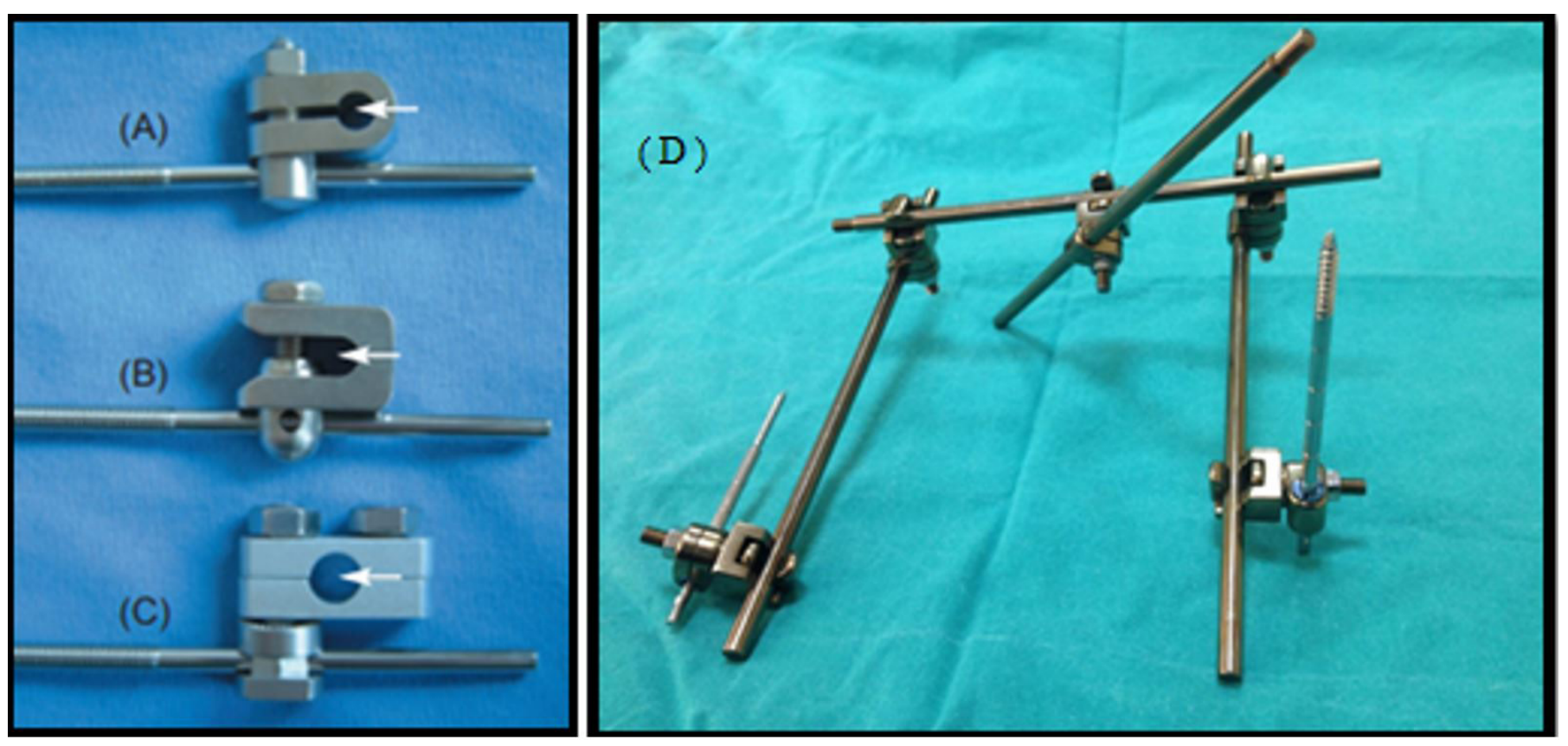

Figure 5 - Clamps of VEF. Figure 5a shows Kirschner-Ehmer, Figure 5b Securos, and Figure 5c IMEX-SK clamps. White arrows show the holes that rods pass. In Figure 5d semi-locked clamps are displayed holding bars and fixator pins in different angles. They can be attached to any rod. The clamp can rotate $360^{\circ}$. It fixes the fixation pin and rod when tightened with a screwdriver. 
positive profile fixator pins via VEF's double pin holding clamps. Steinmann pins that were thought not to break the bone can be applied through oblique and comminuted fracture fragments with these clamps. Acrylic external fixator systems have the same advantage (Shahar, 2000). However, it is not possible to change the configuration of the fixator when it is rigid. The distance between the holes of the double pin holding clamp is $15 \mathrm{~mm}$. This makes it easy to manage short fragments to implement two pins with one clamp. Normally when two clamps are used in a short fragment, they may overlap on the rod because of the inadequate space at the short fragment side. The double pin holding clamps occupied a smaller space than the counter side, where two clamps were used, as shown in Figure 4. Gaining space may be advantageous in many configurations. Using one double pin holding clamp instead of two standard clamps makes the fixator slightly lighter, which may be of great importance especially in small animals.

Movement can occur between the clamp and fixator pin, which can loosen the pin from the clamp. Mostly inappropriate safe corridors, pin tract infection, type II fixators, heat while pinning may cause this problem by pin-bone loosening and increasing the load on the clamps (Gemmill et al., 2004; Gilley et al., 2009). The blue pin holders inserted into the clamps' holes increase the frictional force between the inner and outer contact surfaces. Positive profile fixator pins pass through the hole of pin holders. The outer surface of the pin holder is in contact with the inner surface of the clamp hole. The advantage of frictional force is used in standard and semi-locked clamps by creating increased contact areas. There was no movement observed between clamps, pins, and bars of VEF considering 33 patients. The material strength of the clamps and bars was out of the scope of this study. VEF is made of titanium alloy, which is used to produce fixator materials by Serbay ${ }^{\circ}$.

Earlier callus formation and a diminished healing time for comminuted fractures were not observed compared to other external fixators types (Gemmill et al., 2004;
Könning et al., 2013; Kraus et al., 2003; Langley-Hobbs et al., 1997). According to simple fractures, young patients healed early, and complicated fractures took more time to heal. This shows that VEF has no superiority over IMEX-SK and Securos fixators when healing time and callus formation are taken into account. However, operation success depends on fracture type, infection, the time elapsed after accident, fixation technique, surgeon's experience, patient's temperament, environment, and postoperative care (Beever et al., 2018).

The costs of VEF materials are the same as the IMEXSK and Securos fixators. VEF has no cost advantage over other external fixators.

\section{Conclusion}

Most of the fracture types can be fixed with new generation linear external fixators. Problematic and thin diameter bone fractures need an extra advantage to successfully heal. Pin holders, the double pin holding clamps, and semi-locked clamps do not exist in these external fixators.

We think that VEF does not have specific stability superiority over the Securos and IMEX-SK linear external fixators. However, with its different clamps, VEF has implementation simplicity compared to new generation fixators while constructing them. Saving time and using fewer clamps, when needed, will be beneficial for surgeons.

\section{Conflict of interest}

There is no conflict of interest between the authors.

\section{Ethics Statement}

The Local Ethics Committee of Animal Experiments approved the study at İstanbul University-Cerrahpaşa with report number 72 .

\section{Acknowledgments}

We would like to thank İstanbul University-Cerrahpaşa Scientific Search Projects (BAP) for the funding of the study.

\section{References}

Aronsohn MG, Burk R. Unilateral uniplanar external skeletal fixation for isolated diaphyseal tibial fractures in skeletally immature dogs. Vet Surg. 2009;38(5):654-8. http://dx.doi. org/10.1111/j.1532-950X.2009.00553.x. PMid:19573070.

Auger J, Dupuis J, Boudreault F, Pare P, Beauregard G, Breton L. Comparison of multistage versus one-stage destabilization of a type II external fixator used to stabilize an oblique tibial osteotomy in dogs. Vet Surg. 2002;31(1):10-22. http://dx.doi. org/10.1053/jvet.2002.29452. PMid:11778163.

Beck JA, Simpson DJ. Type 1-2 hybrid external fixator with tied-in intramedullary pin for treating comminuted distal humeral fractures in a dog and a cat. Aust Vet J. 1999;77(1):18- 
20. http://dx.doi.org/10.1111/j.1751-0813.1999.tb12417.x. PMid:10028386.

Beever L, Giles K, Meeson R. Postoperative complications associated with external skeletal fixators in cats. J Feline Med Surg. 2017;19(7):727-36. http://dx.doi. org/10.1177/1098612X17699466. PMid:28592224.

Beever LJ, Giles K, Meeson RL. Postoperative complications associated with external skeletal fixators in dogs. Vet Comp Orthop Traumatol. 2018;31(2):137-43. http://dx.doi. org/10.1055/s-0038-1627477. PMid:29534282.

Canapp SO Jr. External fracture fixation. Clin Tech Small Anim Pract. 2004;19(3):114-9. http://dx.doi.org/10.1053/j. ctsap.2004.09.003. PMid:15712457.

Clarke SP, Carmichael S. Treatment of distal diaphyseal fractures using hybrid external skeletal fixation in three dogs. J Small Anim Pract. 2006;47(2):98-103. http://dx.doi. org/10.1111/j.1748-5827.2006.00014.x. PMid:16438698.

Corr SA. Practical guide to linear external skeletal fixation in small animals. In Pract. 2005;27(2):76-85. http://dx.doi. org/10.1136/inpract.27.2.76.

Fox SM, Bray JC, Guerin SR, Burbridge HM. Antebrachial deformities in the dog: treatment with external fixation. J Small Anim Pract. 1995;36(7):315-20. http://dx.doi. org/10.1111/j.1748-5827.1995.tb02936.x. PMid:7474962.

Foxworthy M, Pringle RM. Dynamization timing and its effect on bone healing when using the orthofix dynamic axial fixator. Injury. 1995;26(2):117-9. http://dx.doi. org/10.1016/0020-1383(95)92189-H. PMid:7721463.

Fragomen AT, Rozbruch SR. The mechanics of external fixation. HSS J. 2007;3(1):13-29. http://dx.doi.org/10.1007/ s11420-006-9025-0. PMid:18751766.

Gemmill TJ, Cave TA, Clements DN, Clarke SP, Bennett D, Carmichael S. Treatment of canine and feline diaphyseal radial and tibial fractures with low-stiffness external skeletal fixation. J Small Anim Pract. 2004;45(2):85-91. http://dx.doi. org/10.1111/j.1748-5827.2004.tb00208.x. PMid:14984151.

Gilley RS, Beason DP, Snyder DM, Boston RC, Radin A, Kapatkin AS, Smith GK, Soslowsky LJ. External fixator clamp reuse degrades clamp mechanical performance. Vet Surg. 2009;38(4):530-6. http://dx.doi.org/10.1111/j.1532950X.2009.00521.x. PMid:19538676.
Giotakis N, Narayan B. Stability with unilateral external fixation in the tibia. Strategies Trauma Limb Reconstr. 2007;2(1):13-20. http://dx.doi.org/10.1007/s11751-0070011-y. PMid:18427910.

Guerin SR, Lewis DD, Lanz OI, Stalling JT. Comminuted supracondylar humeral fractures repaired with a modified type I external skeletal fixator construct. J Small Anim Pract. 1998;39(11):525-32. http://dx.doi.org/10.1111/j.1748-5827.1998. tb03699.x. PMid:9846315.

Johnson AL. Fundamentals of orthopedic surgery and fracture management. In: Fossum TW, editor. Small animal surgery. 5th ed. Missouri: Elsevier; 2018.

Könning T, Maarschalkerweerd RJ, Endenburg N, Theyse LFH. A comparison between fixation methods of femoral diaphyseal fractures in cats - a retrospective study. J Small Anim Pract. 2013;54(5):248-52. http://dx.doi.org/10.1111/ jsap.12061. PMid:23560936.

Kraus KK, Toombs JP, Ness MG. External fixation in small animal fixation. USA: Blackwell Science Ltd.; 2003. p. 5-59. http://dx.doi.org/10.1002/9780470760178.ch1.

Langley-Hobbs SJ, Carmichael S, McCartney WT. External skeletal fixation for stabilisation of comminuted humeral fractures in cats. J Small Anim Pract. 1997;38(7):280-5. http://dx.doi.org/10.1111/j.1748-5827.1997.tb03465.x. PMid:9239628.

Lewis DD, Cross AR, Carmichael S, Anderson MA. Recent advances in external skeletal fixation. J Small Anim Pract. 2001;42(3):103-12. http://dx.doi.org/10.1111/j.1748-5827.2001. tb02006.x. PMid:11303852.

Marcellin-Little DJ. External skeletal fixation. In: Slatter D, editor. Text book of small animal surgery. 3 rd ed. Missouri: Saunders; 2003. p. 1818-34.

Mora G, Forriol F. Mechanical analysis of the healing of different osteotomies fixed externally. Int Orthop. 2000;24(5):295-8. http://dx.doi.org/10.1007/s002640000169. PMid:11153463.

Palmer RH. External fixators and minimally invasive osteosynthesis in small animal veterinary medicine. Vet Clin N Am-Small. 2012;42(5):913-34. http://dx.doi.org/10.1016/j. cvsm.2012.06.001.

Petfield JL, Hayeck GT, Kopperdahl DL, Nesti LJ, Keaveny TM, Hsu JR. Virtual stress testing of fracture stability in 
soldiers with severely comminuted tibial fractures. J Orthop Res. 2017;35(4):805-11. http://dx.doi.org/10.1002/jor.23335. PMid:27302535.

Piermattei DL, Flo GL, DeCamp CE. Handbook of small animal orthopedics and fracture repair. 5th ed. Missouri: Saunders Elsevier; 2016. p. 41-99. http://dx.doi.org/10.1016/ B978-1-4377-2364-9.00002-1.

Roe S. Comparative evaluation of in vitro mechanical properties of different designs of epoxy-pin external skeletal fixation systems. Vet Surg. 2014;43(7):897-8. http://dx.doi. org/10.1111/j.1532-950X.2014.12266.x. PMid:25145679.

Rovesti GL. Complications in external skeletal fixation. In: Griffon D, Hamaide A, editors. Complications in small animal surgery. Iowa: John Wiley \& Sons; 2016. p. 110-7. http://dx.doi.org/10.1002/9781119421344.ch106.

Seibert RL, Lewis DD, Coomer AR, Sereda CW, Royals SR, Leasure CS. Stabilisation of metacarpal or metatarsal fractures in three dogs, using circular external skeletal fixation. N Z Vet J. 2011;59(2):96-103. http://dx.doi.org/1 0.1080/00480169.2011.552860. PMid:21409737.

Shahar R. Relative stiffness and stress of type I and type II external fixators: acrylic versus stainless-steel connecting bars a theoretical approach. Vet Surg. 2000;29(1):59-69. http://dx.doi.org/10.1111/j.1532-950X.2000.00059.x. PMid:10653496.

Sylvestre AM. Fracture management for the small animal practitioner. 5th ed. Hoboken, USA: John Wiley \& Sons; 2019. p. 235-243. http://dx.doi.org/10.1002/9781119215950.

Wander K. External fixators. In: Sylvestre AM, editor Fracture management for the small animal practitioner. Iowa: John Wiley \& Sons; 2019. p. 235-243. http://dx.doi. org/10.1002/9781119215950.ch22

White DT, Bronson DG, Welch RD. A mechanical comparison of veterinary linear external fixation systems. Vet Surg. 2003;32(6):507-14. http://dx.doi.org/10.1111/j.1532950X.2003.00507.x. PMid:14648528.

Witte PG, Bush MA, Scott HW. Management of feline distal tibial fractures using a hybrid external skeletal fixator. J Small Anim Pract. 2014;55(11):571-8. http://dx.doi.org/10.1111/ jsap.12277. PMid:25297567.

Financial Support: This study is supported by İstanbul University-Cerrahpaşa BAP Unit (Project No: 10328). 